\title{
Feeding Ecology of Chinkara (Gazella Bennetti Sykes) in Desert National Park, Rajasthan, India
}

Jaipal BR*

Department of Zoology, Jai Narain Vyas University, Jodhpur, Rajasthan, India

*Corresponding author: BR Jaipal, Department of Zoology, Jai Narain Vyas University, Jodhpur, Rajasthan, India, Tel: 02912625225; E-mail: brjaipal.jnvu@gmail.com Received date: May 20, 2015; Accepted date: Jun 02, 2015; Published date: June 09, 2015

Copyright: (c) 2015, Jaipal BR, This is an open-access article distributed under the terms of the Creative Commons Attribution License, which permits unrestricted use, distribution, and reproduction in any medium, provided the original author and source are credited.

\begin{abstract}
Chinkara (Gazella bennetti) is the state animal of Rajasthan and protected under the schedule- I of Wildlife (Protection) Act, 1972. This is herbivore and mainly found in arid and semi-arid regions. Survival of the chinkara is depended on the natural vegetations those are found in its surrounding habitats. Chinkara feeds mainly on twigs, leaves, flowers and fruits of small trees, bushes, grasses and herbs etc. The study was conducted on the feeding ecology of chinkara in Desert National Park. Direct observation technique was used for taking observations. Seasonal variations were found in its feeding preference. During monsoon season chinkara mostly likes grasses and herbs whereas in summer it feeds upon leaves, twigs, flowers, fallen pods and fruits of bushes and trees. Maximum grazing activities were recorded in monsoon season whereas maximum browsing activities were recorded in summer season.
\end{abstract}

Keywords: Chinkara; Desert national park; Season; Grazing; Browsing

\section{Introduction}

Desert Wildlife Sanctuary is famous as name of the "Desert National Park". It is situated at the heart of the Thar desert near IndoPak boarder. It supports vide variety of desert fauna and flora. Kankane [1] listed about 21 species of mammals from Desert National Park. Chinkara and other mammalian are frequently seen here. In the western Rajasthan Chinkara is known as 'Chhinkaro'. It is distributed in arid and semi-arid regions of India while density is low in most areas [2]. Chinkara was once common even in the salt ranges in the Pakistan and Punjab [3]. Its distribution is wide which ranges from extensive sand dune areas, the rocky plateaus and hilly regions of up to $1500 \mathrm{~m}$ elevation [4]. Chinkara is not only grazer but also browser. Feeding habits are depended on the presence of food type and quantity.

\section{Study Area}

Three specific sites (Sudasari, Khuri and Kanoi) of desert wildlife sanctuary were selected for the study. Sudasari study site is $40 \mathrm{~km}$ south-west to Jaisalmer and lies at $26^{\circ} 43^{\prime} \mathrm{N}$ latitude and $70^{\circ} 35^{\prime} \mathrm{E}$ longitudes. It is a core area surrounded by wire fencing. The habitat is plain ground with Lasiurus sindicus (Sevan grass) and bushes. The Khuri site is situated at $40 \mathrm{~km}$ south to Jaisalmer city. It lies between $26^{\circ} 36^{\prime} \mathrm{N}$ latitude and $70^{\circ} 43^{\prime} \mathrm{E}$ longitudes. It is not a closed area. It is sandy area with undulating sand dunes of about 20-60 feet height. The inter-dunal space between two sand dunes is locally called 'Bewar'. Sand dunes are naked or rare vegetation found on them however, Bewar have rich vegetations. The Kanoi is $35 \mathrm{~km}$ west to Jaisalmer city on Sam road and lies at $26^{\circ} 46^{\prime} \mathrm{N}$ latitude and $70^{\circ} 34^{\prime} \mathrm{E}$ longitudes. It is rocky area with gravel plain and hillock.

\section{Methods}

Food matters used by the Chinkara were assessed by the direct observation [5] and fecal pellet analysis techniques. During study period $8 \times 40$ field binocular was applied to record the feeding activities. Fecal pellets were collected from different study sites (periodically) in every season. These were stored in plastic bags dismembered with the help of needle and forceps and undigested material such as seeds, small twigs of different plant were separated.

\section{Result and Discussion}

\section{Feeding habits}

During study period total 447 observations of feeding were taken. It was observed that Chinkara browsed maximum (73.50\%) in summer season and lowest (36.87\%) in monsoon season. Chinkara was observed grazing highest (63.12\%) during monsoon season followed by winter $(38.77 \%)$ and summer $(26.49 \%)$ during the study period (Table 1). In previous study Gehlot [5] reported that Chinkara grazing was highest $(35.16 \%)$ during monsoon season followed by winter (33.9\%) and summer $(23.32 \%)$.

\begin{tabular}{|l|l|l|l|}
\hline Season & $\begin{array}{l}\text { No. of } \\
\text { observation }\end{array}$ & $\begin{array}{l}\text { Grazing in natural } \\
\text { habitat (\%) }\end{array}$ & $\begin{array}{l}\text { Browsing in natural } \\
\text { habitat (\%) }\end{array}$ \\
\hline Winter & 147 & 38.77 & 61.22 \\
\hline Summer & 151 & 26.49 & 73.50 \\
\hline Monsoon & 179 & 63.12 & 36.87 \\
\hline
\end{tabular}

Table 1: Feeding habits (patterns) of Chinkara observed during the study period. 
Citation: Jaipal BR (2015) Feeding Ecology of Chinkara (Gazella Bennetti Sykes) in Desert National Park, Rajasthan, India. J Biodivers

Page 2 of 4

\section{Feeding preferences}

Food is of prime importance throughout an individual life. Moving, resting, playing and all other routine activities were influenced by the availability of food. Survival of the Indian gazelle depended on the natural vegetations those were found in harsh Desertic condition.

We found the Chinkara feeding on 61 plant species of which 9 were field plant and 52 were wild. Gazelle have been observed eating on herbs like Sinawari (Boerhavia diffusa), Chag (Crotalaria burhia), Bekar (Indigofera spp.), Lamp (Aristida spp.), Matira (Citrullus lanatus), Tumba (Citrullus colocynthis), Kilandh (Convolvulus mycrophyllus), Kanti (Tribulus terresteris), grasses like Sevan (Lasiurus sindicus), Tantia (Dactyloctenium sindicus), Murat (Penicum turgidum), Karad (Dichanthium annulatum), Dhaman (Cenchrus ciliaris), Bhurat (Cenchrus biflorus), moth (Cyperus rotundus) and twigs, leaves, flowers and fruits of small trees like Kumat (Acacia senegal), Israeli babul (Acacia tortilis), Khejri (Prosopis cineraria), Angreji babul (Prosopis juliflora), Jal (Salvadora spp.) and on bushes like Morali (Lycium barbarum), Gangani (Grewia tenax), Aak (Calotropis procera), Bordi (Ziziphus spp.), Ker (Capparis decidua), Thor (Euphorbia caducifolia) etc. (Table 2). In previous study Gehlot [5] reported that Chinkara preferred 39 wild plants species and 5 crop plants for feeding.

\begin{tabular}{|c|c|c|c|c|}
\hline Botanical name & $\begin{array}{l}\text { Common } \\
\text { name }\end{array}$ & Summer & Winter & Monsoon \\
\hline $\begin{array}{l}\text { Trianthema } \\
\text { portulacastrum }\end{array}$ & Sato & W & - & - \\
\hline Calotropis procera & Aak & Yt, P, F, L & Yt, F, L & $\mathrm{F}, \mathrm{L}$ \\
\hline $\begin{array}{l}\text { Leptadenia } \\
\text { pyrotechnica }\end{array}$ & Kheemp & Dt, Yt & Yt & - \\
\hline Odontanthera virians & Dodha & - & - & W \\
\hline Aerva javanica & Bui & Dt, L & L & - \\
\hline Tecomella undulata & Rohida & $\mathrm{fl}, \mathrm{L}$ & $\mathrm{fl}$ & - \\
\hline Arnebia hispidissima & Ram bui & $\mathrm{Dt}$ & $D t$ & W \\
\hline Capparis decidua & Ker & $\mathrm{Dt}, \mathrm{Yt}, \mathrm{F}, \mathrm{P}$ & Yt, Dt, F & Yt, P \\
\hline Citrullus colocynthis & Tumba & $\mathrm{R}$ & $\mathrm{R}$ & $P$ \\
\hline Citrullus lanatus & Matira & - & $\mathrm{R}$ & $\mathrm{P}$ \\
\hline Cucumis caliosus & Kachrio & - & - & $\mathrm{P}$ \\
\hline Cucumis melo & Kachri & - & - & $\mathrm{P}$ \\
\hline Cucumis prothetarum & Khar kachrio & - & - & $P$ \\
\hline Cyperus arenarius & Moth & W & W & - \\
\hline $\begin{array}{l}\text { Convolvulus } \\
\text { microphyllus }\end{array}$ & Kilandh/Sintar & W & W & W \\
\hline Euphorbia caducifolia & Thor & Yt, F & Yt, F & - \\
\hline Crotalaria burhia & Chag & W & W & W \\
\hline $\begin{array}{l}\text { Cyamopsis } \\
\text { tetragonoloba }\end{array}$ & Gawar & - & - & W \\
\hline Indigofera cordifolia & Bekar & $\mathrm{Dt}$ & Dt & W \\
\hline
\end{tabular}

\begin{tabular}{|c|c|c|c|c|}
\hline Indigofera hochstetteri & Adio bekar & $\mathrm{Dt}$ & $\mathrm{Dt}$ & W \\
\hline Indigofera linifolia & Lambio bekar & $\mathrm{Dt}$ & $\mathrm{Dt}$ & W \\
\hline Indigofera oblongifolia & Jhil & $\mathrm{Dt}$ & $\mathrm{Dt}$ & W \\
\hline Boerhavin diffusa & Sinawari & $\mathrm{Dt}$ & $\mathrm{Dt}$ & W \\
\hline Acacia nilotica & Desi babul & $\mathrm{fl}$ & - & - \\
\hline Acacia senegal & Kumat & $\mathrm{fl}, \mathrm{L}$ & $L, f p$ & - \\
\hline Acacia tortilis & Israili babul & $\mathrm{L}, \mathrm{fl}$ & $L, Y t$ & - \\
\hline Prosopis cineraria & Khejri & $\mathrm{fl}, \mathrm{fp}, \mathrm{F}$ & $\mathrm{L}, \mathrm{Yt}$ & $\mathrm{L}, \mathrm{Yt}$ \\
\hline Prosopis juliflora & Angreji babul & $f p, P$ & $P, f p$ & - \\
\hline Mollugo cervina & Chirio ro khet & $\mathrm{Dt}$ & $\mathrm{Dt}$ & W \\
\hline Lasiurus sindicus & Sevan grass & W & W & W \\
\hline Cenchrus biflorus & Bhurat & $\mathrm{Dt}, \mathrm{L}$ & $\mathrm{Dt}, \mathrm{L}$ & $\mathrm{L}$ \\
\hline Cenchrus ciliarus & Dhaman & W & $\mathrm{Dt}, \mathrm{L}$ & $\mathrm{L}$ \\
\hline Cenchrus prieurii & Lambio Bhurat & W & $\mathrm{Dt}, \mathrm{L}$ & $L, P$ \\
\hline $\begin{array}{l}\text { Desmostachiya } \\
\text { bipinnata }\end{array}$ & Dab & W & - & - \\
\hline Panicum antidotale & Gramno & W & - & - \\
\hline Panicum turgidum & Murat & W & $L, T$ & - \\
\hline $\begin{array}{l}\text { Dactyloctenium } \\
\text { sindicus }\end{array}$ & Tantia grass & w & W & W \\
\hline $\begin{array}{l}\text { Dactyloctenium } \\
\text { aegyptium }\end{array}$ & Zernia grass & W & W & W \\
\hline Dichanthium annulatum & Karad & W & - & - \\
\hline Aristida adscensionis & Lamp & W & W & W \\
\hline Aristida funiculate & Lamp & W & W & W \\
\hline Aristida hystriculata & Dholiolamp & W & W & W \\
\hline Aristida Mutabelis & Lamp & W & W & W \\
\hline Brachiaria ramosa & Murat Makra & W & - & - \\
\hline Ziziphus mauritiana & Ber & $\mathrm{fl}, \mathrm{F}$ & Yt, L,P & $\mathrm{Yt}, \mathrm{L}$ \\
\hline Ziziphus nummularia & Ber & $\mathrm{fl}, \mathrm{L}$ & $\mathrm{Yt}, \mathrm{L}$ & $Y t, L, P$ \\
\hline Salvadora persica & Mithi Jal & $L, f L, P$ & $\mathrm{~L}$ & - \\
\hline Salvadora oelioedis & Khari Jal & $L, f L$ & $\mathrm{~L}$ & - \\
\hline Lycium barbarum & Morali & $\mathrm{fl}, \mathrm{L}, \mathrm{Dt}$ & L, Yt & - \\
\hline Corchorus depressus & Chamgrass & - & -- & W \\
\hline Chorchorus tricularis & Hade ka Khet & - & $\mathrm{Dt}$ & W \\
\hline Chorchorus olitorius & Hade ka khet & - & $\mathrm{Dt}$ & W \\
\hline Chorchorus trident & Kag nasha & - & $\mathrm{Dt}$ & W \\
\hline Grewia tenax & Gangani & $\mathrm{fl}, \mathrm{L}, \mathrm{Dt}$ & $\mathrm{L}, \mathrm{Yt}$ & $L, p$ \\
\hline Tribulus pentadrus & Dhakda & $\mathrm{Dt}$ & $\mathrm{Dt}$ & W \\
\hline
\end{tabular}


Page 3 of 4

\begin{tabular}{|l|l|l|l|l|}
\hline Tribulus terrestris & Kanti & Dt & Dt & W \\
\hline Fagonia bruguieri & Dhamasa & Dt & - & - \\
\hline Fagonia schweinfurthii & Dhamasa & Dt & - & - \\
\hline Pennisetum glaucum & Bajra & - & - & L \\
\hline Vigna radiata & Mung & - & - & L, P, Yt \\
\hline Sismum indicum & Til & - & - & L, P \\
\hline
\end{tabular}

Table 2: Plants and their parts used by the Chinkara in different seasons. L-Leaves, F- Flowers, P- Pods, W-Whole, R-Root, Dt-Dry twigs, Yt- Young twigs, fl- Fallen leaves, fp-Fallen pods or fruits.

\section{Seasonal variations}

Seasonal variations were observed in food preferences in different study areas. The food preferences were depended upon availability of food. During winter Chinkara started feeding activity after sun rise and it continued throughout the day. Chinkara took rest for short intervals during feeding activities in winter and monsoon season. During summer and monsoon feeding activities were observed in the night.

\section{Winter}

In winter gazelle scraped soil with forefeet to expose the roots of Tantia (Dactyloctenium sindicus), Moth (Cyperus arenarius), Tumba (Citrullus colocynthis), Bui (Aerva javanica), Sinawari (Boerhavia diffusa), and Ber (Ziziphus spp.) for food and water. Chinkara mostly preferred Chag (Crotalaria burhia) followed by Ber (Ziziphus sp). Khejri (Prosopis cineraria), Ker (Capparis decidua) and Aak (Calotropis procera), but it did not prefer Dab (Dichanthium annulatum), Dhamasa (Fagonia spp.) and Gramno (Panicum antidotale) during winter season (Table 2).

Sudasari is a close area and vegetation was not consumed by livestock, thus at Sudasari site Chinkara grazed on dry parts of grasses, herbs, and browsed on twigs and leaves of bushes and small trees. But Khuri and Kanoi study sites were not closed area so most of the vegetation were consumed by the livestock. As a result gazelle grazed on Chag (Crotalaria burhia), dry parts of Murat (Panicum turgidum), Tantia (Dactyloctenium sindicus) and browsed on bushes and small trees. Chinkara became more browser during winter season.

\section{Summer}

In summer when leaves and twigs were not available on lower branches of bushes and small trees, Chinkara reared up on his hind legs to browse the parts of small trees and bushes. Gazelle eats on leaves, twigs, flowers and fruits of bushes and fallen pods, fruits and leaves of trees. As mentioned earlier the Sudasari study site is a closed site so dry grasses and parts of herb were available in summer season also, so gazelle grazed on them. In Khuri study site only parts of Israeli babul (Acacia tortilis) and Angreji babul (Prosopis juliflora) and leaves and pods were available for browsing and consumed by gazelle (Table 2). In early study Ghosh et al. [7] and Goyal et al. [8] reported that Indian gazelle consumed more fruits, pods, flowers and fallen leaves of preferred plants during summer season.

\section{Monsoon}

During monsoon gazelle mostly liked grasses and grazed on Sevan grass (Lasiurus sindicus), Tantia grass (Dactyloctenium sindicus), Kanti (Tribulus terrestris), Lamp (Aristida spp.), Sintar (Convolvulus microphyllus), Sinawari (Boerhavia diffusa), Bekar (Indigofera spp.), Hade ka khet (Chorchorus spp.) and for browsing they preferred Bordi (Ziziphus spp.), Khejri (Prosopis cineraria) and fruits of Ker (Capparis decidua). In monsoon season Israeli babul (Acacia tortilis), Bui (Aerva javanica), Kheemp (Leptadenia pyrotechnica), Murat (Penicum turgidum), Dhamasa (Fagonia spp.), Angreji babul (Prosopis juliflora) and Jal (Salvadora spp.) were not preferred by the gazelle (Table 2).

Fecal matter analysis showed the presence of seeds of different plants. In summer season seeds of Ker, Khejri and Jal were observed in fecal pellets. In winter seeds of Chag, and Ker were observed. In monsoon season seeds of Ber, Ker, Hade ka khet, Gangani, Matira, Kachri, Moth, Mung and Guar were observed. In previous study Gehlot [9] reported seeds of Chag, Moth and Mung in fecal pellets of Chinkara. Dookia [10] reported that Chinkara feed mainly four plants viz., Crotalaria burhia, Ziziphus nummularia, Mayterus emerginata and Prosopis cineraria which constitute overall $77 \%$ of total dietary requirements. The present study showed that chinkaras feeds upon more number of plant species as stated in the earlier studies $[9,10]$ for its feeding behavior. Feeding habits are depended on the presence of food quality and quantity. The preference of the feeding related to the vegetation types alteration during the different seasons in the desert. The large feeding range of this antelope is helpful for the survival of species in the harsh climatic conditions of extreme desert.

\section{Acknowledgements}

This author expresses gratitude to the authorities of Forest Department, Govt. of Rajasthan for granting him necessary permission for the studies on the referred animal in DNP. He is further thankful to the Head, Department of Zoology, JNV University, Jodhpur for the provided laboratory facilities and Prof. G. R. Jakher is hereby thanked for guidance regarding the present research work. Dr. Himmat Singh, DMRC Jodhpur for necessary support.

\section{References}

1. Kankane PL (2000) Status Survey of Chinkara and Desert Cat in Rajasthan. Rec Zool India 179: 71.

2. Rahmani AR (1990) Distribution of the Indian Gazelle or Chinkara Gazella bennetti (Sykes) in India. J Mammalia 4: 605-619.

3. Prater SH (1971) The Book of Indian Animals. (Bombay) Nat Hist Soc, India, pp: 78.

4. Roberts TJ (1977) The Mammals of Pakistan. Earnest Benn Ltd, London, pp: 361.

5. Altman J (1974) Observational study of behaviour: Sampling methods. Behaviour 49: 227-267.

6. Gehlot HS, Jakher GR (2010) Feeding Behaviour and Habitat Preference of Indian Gazelle (Gazella bennetti Sykes) in the Thar Desert of Rajasthan, India. In: Impact of Climate Change on Biodiversity and Challenges in Thar Desert 332-336 pp.

7. Ghosh PK, Goyal SP, Bohra HC (1987) Competition for resources utilization between wild and domestic ungulates in the Rajasthan desert. Tiger Paper 14: 2-7.

8. Goyal SP, Bohra HC, Ghosh PK, Prakash I (1988) Role of Prosopis cineraria pods in the diet of two Indian desert antelopes. J Arid Env 14: 285-290. 
Citation: Jaipal BR (2015) Feeding Ecology of Chinkara (Gazella Bennetti Sykes) in Desert National Park, Rajasthan, India. J Biodivers Endanger Species 3: 155. doi:10.4172/2332-2543.1000155

Page 4 of 4

9. Gehlot HS (2006) Social organization, Behavioural and Resources selection pattern in Antelope cervicapra and Gazella bennetti of Thar Desert.
10. Dookia S (2009) Conservation of Indian Gazelle or Chinkara through community support in Thar desert of Rajasthan, India. 